JANUSZ GRYGIEŃĆ

Instytut Politologii UMK

\title{
Autonomia, irracjonalizm i wspólnota. Szkic o filozoficzno- politycznych wymiarach Nowej Heloizy J. J. Rousseau
}

W przedmowie do Dziedzictwa cnoty Alasdaira MacIntyre'a Adam Chmielewski napisał, że historia filozofii zna nazwiska postaci, które - przełamując pewien dominujący typ dyskursu - wymykają się klasyfikacjom. Gdy uda się włączyć je w ramy szerszych rozważań, „okazuje się, że nowo wyznaczone współrzędne filozoficzne lokalizują nieznane obszary badawcze, dotychczas terra incognita, co zmusza do rewizji obszaru całej «geografii» filozoficznej. Tacy filozofowie są odkrywcami nowych kontynentów ludzkiej myśli, a ich nazwiska stają się symbolami dla nowych paradygmatów"1. Bez wątpienia słowa te znajdują zastosowanie w odniesieniu do MacIntyre'a. Równie dobrze mogą one także opisywać autora Nowej Heloizy.

Nie będę próbował, skrótowo nawet, wskazywać elementów filozofii Jana Jakuba Rousseau, które mogą świadczyć o jej wyjątkowości, niebanalności, czyniącej wspomniane, historyczno-filozoficzne klasyfikacje bardzo trudnymi, natomiast możliwości ich krytyki - bardzo prostymi. Poprzestanę na prostej konstatacji, że uznanie nietuzinkowości rousseau'owskiego dorobku filozoficznego, czy choćby liczne pytania o jego spójność, zdają się stanowić prostą konsekwencję dwóch czynników. Pierwszy to brak systema-

A. Chmielewski, Filozofia moralności Alasdaira MacIntyre'a w: A. MacIntyre, Dziedzictwo cnoty, przeł. A. Chmielewski, Warszawa 1996, s. x. 
tycznej wiedzy filozoficznej autora Umowy społecznej. Z jego powodu - czynione w tekstach Rousseau - odniesienia do tradycji rozpatrywania kwestii etycznych czy politycznych oraz język, jakim się posługuje, w niewielkim jedynie stopniu pozwalają na wyciąganie wniosków o pokrewieństwie z filozofiami wcześniejszymi. O wpływie, jaki na Rousseau wywarły: platoński projekt polityczny, rzymski stoicyzm, sceptycyzm Montaigne'a czy O Duchu praw Monteskiusza, pisano wiele, ale panuje powszechna zgoda co do tego, że nazwanie autora Umowy... stoikiem, sceptykiem czy platonikiem musi wywołać co najmniej uśmiech każdego, kto jest z jego dziełami zapoznany. Po drugie, na kształt filozofii Rousseau zapewne rzutował trudny i skomplikowany charakter tego myśliciela oraz jego bogate życiowe doświadczenia. Był człowiekiem marzącym o świecie antycznych ideałów obywatelstwa i bohaterstwa, którymi zachwycał się od dzieciństwa. Prawość poruszeń serca, żelazna konsekwencja działań, odpowiedzialność za współobywateli i wspólnotę - umiłowanie tych cnót wyniósł z lektury Żywotów sławnych mężów Plutarcha. Przez to między innymi był człowiekiem zawieszonym między przynajmniej trzema epokami. Z jednej strony, przyszło mu żyć w wieku Oświecenia, wzrastać intelektualnie w atmosferze wiary w potęgę ludzkiego rozumu, w zwątpieniu w jakąkolwiek wartość irracjonalizmu, w siłę i słuszność autorytetu, tak moralnego, jak i politycznego. Drugi wpływ - kontrastujący z pierwszym - to ten antyczny. Najbardziej przebija on $\mathrm{z}$ politycznych pism Rousseau, w szczególności z ułożenia relacji jednostki do wspólnoty, z powrotu do teleologicznego ujęcia roli państwa. W końcu, Rousseau to także po części człowiek romantyzmu. Fascynacja, z jaką późniejsi przedstawiciele Sturm und Drang zagłębiali się w lekturze jego pism, fakt poświęcenia mu wierszy choćby przez Hölderlina, nie były przypadkowe. Antyczne fascynacje, połączone $\mathrm{z}$ właściwym temu autorowi sentymentalizmem, pchnęły go w kierunku próby „roztopienia” jednostki nie tylko we wspólnocie politycznej, ale także w naturze.

Rousseau jako pierwszy śledzi negatywne skutki psychologicznego indywidualizmu, które doskonale ukazywał osiemnastowieczny Paryż. Obraz osamotnienia, wewnętrznego zagubienia, schlebiania własnym zachciankom prowadzącego do bezrefleksyjnego zafiksowania na nigdy niekończących się próbach powiększenia stanu posiadania, na zabieganiu o nieszczere uznanie innych - to wszystko odpycha go, sprawia, że Rousseau próbuje odwrócić się od swych czasów. Taka wewnętrzna emigracja nie była jednak możliwa, przynajmniej nie do końca. Rousseau, jakkolwiek mocno tego nie chciał, pozostawał człowiekiem Oświecenia. Antropologiczne, społeczne i polityczne, nawet religijne paradygmaty myślenia francuskich luminarzy tej epoki ukształtowały jego myśl i przeniknęły dzieła. 
Ścieranie się tych jakże odmiennych tradycji myślenia o człowieku i o polityce jest szczególnie widoczne przy rozpatrywaniu problemu racjonalizmu bądź irracjonalizmu Rousseau. Kwestia ta dzieli komentatorów jego myśli na dwa opozycyjne obozy. Do pierwszego należą ci, którzy dopatrują się w dziełach autora Umowy... niezłomnego racjonalizmu, zakłóconego nieznacznie ich przesadnie sentymentalnym wydźwiękiem. To ta właśnie grupa badaczy kładzie szczególny nacisk na pokrewieństwo myśli Rousseau i Kanta. Wskazuje się tu fakt dowartościowania przez obu roli ludzkiej autonomii w sferze rozumu praktycznego ${ }^{2}$, znaczenia auto-determinacji i obowiązku w życiu moralnie dobrym, rozdzielenie sfery moralności i prawodawstwa, które ulega niwelacji we wspólnocie idealnej, wreszcie niezastąpioną rolę rozumu zarówno w kształtowaniu właściwego porządku prawnego, jak i rozwiązywaniu dylematów moralnych.

Na przeciwległym biegunie interpretacji myśli Rousseau plasują się ci, którzy widzą w nim przede wszystkim preromantyka skłonnego odrzucić racjonalistyczną retorykę autonomii na rzecz dezyderatu quasi-mistycznego stopienia jednostki ze wspólnotą - ideału politycznego upatrywanego przez autora Umowy społecznej m.in. w instytucjach starożytnej Sparty. Interpretacja „irracjonalistyczna” miałaby także znajdować potwierdzenie w przyznaniu prymatu temu, co „naturalne” nad tym, co „sztuczne” i „kulturowe”, przypadkowości egzystencji wspólnotowej nad uniwersalizmem jusnaturalizmu obecnym nie tylko w pismach współczesnych mu filozofów francuskich, ale także Kanta.

Co dziwne, obie grupy powołują się na te same dzieła Rousseau, częstokroć te same ich fragmenty odczytując zupełnie odmiennie. Dobry przykład stanowi w tym przedmiocie właśnie Nowa Heloiza, choć mogłoby się zdawać, że jest to praca, która do takiej dyskusji nie jest w stanie wnieść praktycznie żadnego wkładu’ ${ }^{3}$. Jest to bowiem, po pierwsze, dzieło pozornie niepolityczne, epistolarny romans dwojga kochanków gloryfikujący „wspólnotę dusz", miejscami tylko powtarzający wcześniej już wypracowane w in-

Zob. A. Kaufman, Reason, Self-Legislation and Legitimacy: Conceptions of Freedom in the Political Thought of Rousseau and Kant, "The Review of Politics" 1997, s. 25-52.

3 Sugestie te znajdują potwierdzenie w praktyce notorycznego pomijania w filozoficznopolitycznych analizach właśnie tego dzieła. Dobry przykład stanowi tu choćby uznana książka Rogera Mastersa (R. D. Masters, The Political Philosophy of Rousseau, Princeton, New Jersey 1976) oraz powszechnie cenione wydanie dzieł Rousseau zredagowane przez Charlesa Edwyna Vaughana (J. J. Rousseau, The Political of Jean-Jacques Rousseau. Edited from the original manuscripts and authentic editions, ed. C. E. Vaughan, t. 1-2, Cambridge 1915). Jednak nie brakuje też głosów uznających polityczną doniosłość Rousseau'owskiego romansu (zob. D. R. Wers, Desire and Duty in „La Nouvelle Heloise”, „Modern Language Studies” 1988, nr 2, s. 79-88). 
nych pismach treści filozoficzne ${ }^{4}$. Po drugie, te filozoficzno-polityczne rozstrzygnięcia, których treści domniemywać można z konstrukcji wspólnotowych form egzystencji przedstawionych w Nowej Heloizie, zdają się być nieprzystające do opisanych $\mathrm{w}$ dziełach wcześniejszych. Niektórzy twierdzą nawet, że podobnie jak inne, nie pasujące do dorobku Rousseau dzieła ${ }^{5}$, tak i to nie powinno być przedmiotem rozważań filozoficznych, a co najwyżej filologicznych. Jedno z uzasadnień takiej tezy wskazuje na fakt, że postulat istnienia i odpowiedniego ułożenia instytucji politycznych, który stanowił warunek sine qua non wyłonienia „woli powszechnej” jeszcze na łamach Umowy..., podobnie jak uznanie konieczności aktywnej partycypacji obywateli $\mathrm{w}$ procesie stanowienia prawa, tu zastąpiony zostaje biernym podporządkowaniem ich władcy, na którego łaskę, niczym hobbesowskiego Lewiatana, zdają się podwładni.

Asumpt dla rozważań na temat tego czy kwestia racjonalizmu pozwala przyporządkować Rousseau bardziej do tradycji Oświecenia czy romantyzmu daje przełożona niedawno na język polski książka Ernsta Cassirera Rousseau, Kant, Goethe $e^{6}$. Nie jest to jedyne dzieło tego autora poświęcone filozofii Oświecenia ${ }^{7}$, ani też samemu Rousseau ${ }^{8}$. Niemniej jednak we wszystkich swych pracach traktujących o tym zagadnieniu, Cassirer prezentuje ściśle określoną wizję filozofii autora Umowy..., co pozwala na traktowanie ich częstokroć jako komplementarnych. Autor ten interpretuje całokształt myśli Rousseau na pierwszy z przedstawionych powyżej sposobów - „racjonalistyczny”. Hołduje przekonaniu, że to właśnie w pismach sławnego Genewczyka należy szukać źródeł wielu koncepcji Kanta. Mimo że dostrzega złożoność intencji samego Rousseau, a także stwierdza jałowość prób ostatecznego rozstrzygnięcia kwestii: racjonalista czy irracjonalista9 ${ }^{9}$ kluczowe kategorie Rousseau'owskiej etyki i filozofii polityki interpretuje wła-

4 Zob. J. Lemaître, Jean-Jacques Rousseau, Paris 1905, s. 209-211. Jeden ze znakomitych wyjątków stanowią w tym przedmiocie dwa listy, z których jeden argumentuje za (cz. III, list XXI), drugi zaś przeciw (cz. III, list XXII) zasadności dokonania aktu samobójstwa (por. M. Janion, Żyjąc tracimy życie, Warszawa 2001, s. 153-157).

5 Raymond Polin za takie dzieło ma Projekt konstytucji dla Korsyki (R. Polin, La politique de la solitude. Essay sur la philosophie politique de Jean-Jacques Rousseau, Paris 1971, s. 132). Podobnie jest z Uwagami nad rządem polskim, które w miejsce, stanowiącej fundament rządów „woli powszechnej” w Umowie społecznej, demokracji bezpośredniej, kompromisowo przyznają rację bytu także demokracjom przedstawicielskim (por. J. Michalski, Rousseau i sarmacki republikanizm, Warszawa 1997).

6 Zob. E. Cassirer, Rousseau, Kant, Goethe, przeł. E. Paczkowska-Łagowska, Gdańsk 2008.

7 Tenże, The Philosophy of Enlightenment, transl. F. C. A. Koelln, J. P. Pettegrove, New Jersey 1979.

8 Zob. tenże, The Question of Jean-Jacques Rousseau, transl. P. Gay, New York 1956.

9 Zob. tamże, s. 39. 
śnie w duchu kantyzmu. Tak jest m.in. z pojęciem wolności jako podporządkowania, „wyższej” niż arbitralna, rozumnej woli ${ }^{10}$.

Jak już zauważyłem, szczególnie kontrowersyjne jest doszukiwanie się potwierdzenia zasadności takiej „racjonalistycznej” interpretacji w Nowej Heloizie - swoistym manifeście literackiego preromantyzmu. Nie ulega wątpliwości, że Rousseau w dziele tym przedstawia pewien typ idealnej wspólnoty „politycznej” - społeczności Clarens obejmującej domowników oraz służbę barona de Wolmar i jego żony Julii. W artykule swym postaram się przybliżyć ten filozoficzno-polityczny projekt i zastanowić się, na ile pozostaje on w opozycji do zaproponowanego w Umowie spolecznej. Mimo wszechobecnych i rozległych, zawartych w Nowej Heloizie, odniesień do kwestii etycznych, które częstokroć można by powiązać z polityką, swoją uwagę skupię wyłącznie na kwestii relacji łączących gospodarzy posiadłości Clarens oraz ich służbę.

„Milordzie, cóż to za miły i wzruszający widok - prosto i dobrze urządzony dom, w którym panują porządek, spokój, niewinność; gdzie bez zbędnego przepychu, bez świetności, zebrano wszystko, co odpowiada rzeczywistemu przeznaczeniu człowieka!"11 - tak oto zachwycony Saint-Preux główny bohater powieści - pragnie zacząć opis domostwa w Clarens.

\section{Prawodawcy - małżeństwo Wolmar}

„Poprawić naturę! - rzekł przerywając mi Wolmar - to piękne słowo"*

Fundament całej „ustrojowej” konstrukcji Nowej Heloizy bez wątpienia stanowią postacie gospodarzy Clarens - barona de Wolmar i jego żony, Julii. Są to rousseau'owskie ideały - podobne głównemu bohaterowi Emila, czyli o wychowaniu. Ich intelektualna autonomia i otwartość usuwa przed nimi przeszkody w rozumowaniu tak powszechne wśród osób „z towarzystwa”. Ich niezależność $\mathrm{w}$ myśleniu, właściwe epoce nie popadanie w przesądy, przede wszystkim zaś ciągła orientacja na działanie „w zgodzie z naturą" w tym należy szukać źródła wyjątkowej roli, jaką odgrywają w życiu ustanowionej i podtrzymywanej własnymi siłami wspólnoty ${ }^{12}$.

Są to ludzie ze wszech miar wyjątkowi. Kto inny niż oni miałby projektować i realizować ustrój „naturalny”, tj. taki, w którym wszystkie istotowe potrzeby ludzkie w równym stopniu znajdują spełnienie? Sam Wolmar to człowiek niemalże pozbawiony namiętności. Jego opanowanie świadczy

$10 \quad$ Zob. tamże, s. 55.

11 J. J. Rousseau, Nowa Heloiza, przeł. E. Rzadkowska, Wrocław-Warszawa-Kraków 1962, s. 233.

Tamże, s. 347.

12 Zob. H. G. Graham, Rousseau, Edinburgh-London 1882, s. 117-118. 
o wyższości. Jak pisze w jednym z listów Julia: ,jest wyższy od nas wszystkich, ludzi uczucia, pełnych dla siebie podziwu; serce bowiem nas oszukuje na tysiąc sposobów i jeśli działa, powołuje się na zawsze podejrzaną zasadę, ale rozum ma cel w tym tylko, co dobre; jego wskazania są pewne, jasne, łatwe do wprowadzenia w życie, nigdy więc nie pobłądzi, chyba w późniejszych spekulacjach, nie dla niego stworzonych"13.

Wszystkie cechy charakteru i umiejętności predestynują gospodarzy do kształtowania osobowości poddanych według własnej woli. „Wyznam ci, milordzie - pisze Saint-Preux - że nigdy nie widziałem, aby ktokolwiek tak, jak tutejsi dziedzice potrafił z tych samych ludzi zrobić służących, wyćwiczonych w obsłudze państwa, wieśniaków, zdatnych do uprawy roli, żołnierzy umiejących bronić ojczyzny i ludzi gotowych do świadczenia dobra w każdym stanie, do jakiego ich los powoła"14.

Rysuje się tu wyraźna analogia między tymi pierwowzorami „władców" a instytucją Prawodawcy wyłożoną przez Rousseau w Umowie społecznej. Législateur to także ktoś „,nadludzki”, gdyż wyzbyty tych wad, którym zazwyczaj się ulega. Jest w nim tym samym coś z mitycznego półboga, w końcu „(T)rzeba by bogów, żeby dawać prawa ludziom"15. Nie wystarczy jednak, że jest to człowiek pozbawiony ułomności. Pozytywna charakterystyka nakłada na niego obowiązek posiadania odpowiednich umiejętności: „(T)rzeba najwyższych umiejętności, aby oświecać, kierować tak ważnym urządzeniem i dojść do szczęśliwych wyników"16. Co obejmują takie umiejętności? Przede wszystkim zdolność wpływania na innych, lecz nie tylko. Chodzi też o stosowne korzystanie z posiadanej wiedzy, gdyż właściwe wykorzystanie informacji na temat ludzkiej „natury”, jej głównych przywar i sposobów przeciwdziałania im - to główne narzędzie Prawodawcy, bez którego może on co najwyżej pozostać samotnym mędrcem, ale nigdy skutecznym władcą.

13 J. J. Rousseau, Nowa..., s. 204. Rysuje się jednak wielka różnica między Wolmarem i rusowskim ideałem jednostki wybitnej. Otóż Wolmar jest ateistą, zaś Rousseau w pozostałych swych dziełach nieprzerwanie piętnuje ateuszy, pisząc m.in. że „ateizm, czyli brak religii w ogóle - filozofia opierająca się jedynie na samym rozumie - przywiązuje do życia, osłabia i upadla dusze koncentrując wszystkie namiętności na linii najbardziej poziomych interesów jednostki, poniżając jaźń ludzką i podkopując w ten sposób nieznacznie główne fundamenty społeczeństwa" (J. J. Rousseau, Emil, czyli o wychowaniu, przeł. W. Husarski, t. 2, Wrocław 1955, s. 156 /przypis/). Zdaje się jednak, że konstrukcja społeczności Clarens, mimo braków jej gospodarza, zyskuje ostateczną podporę w gospodyni (zob. P. Burgelin, La philosophie de l'existence de J.-J. Rousseau, Paris 1952, s. 448-450). Julia okazuje się bowiem być wyznawczynią religii naturalnej na miarę tej, której zasady wyłożone zostały w Wyznaniu wiary wikarego sabaudzkiego (J. J. Rousseau, Nowa..., s. 401-404; por. tenże, Emil..., t. 2, |s. 87-159).

14 Tenże, Nowa..., s. 251; por. s. 265.

15 Tenże, Umowa społeczna, przeł. A. Peretiatkowicz, Kęty 2002, s. 37.

16 Tenże, Nowa..., s. 265. 
Mimo punktów stycznych, rysuje się jednak wyraźnie wiele różnic między Prawodawcą Umowy... i gospodarzem Clarens. Główną z nich stanowi z pewnością fakt, że Umowa... nie przewiduje możliwości instytucjonalizacji tej funkcji. Mimo że jej sprawowanie wymaga odporności na pociąg do władzy i skłonność ku partykularyzmowi własnych interesów, Rousseau nie wierzy, by można było takim pokusom opierać się wiecznie. Fakt uczestnictwa obywateli w sprawowaniu władzy stanowi zatem jedyną prawdziwą gwarancję objawienia nakazów „woli powszechnej”. Poza tym bycie obywatelem, przejmowanie odpowiedzialności za siebie i za innych nie jest możliwe bez świadomości posiadania wpływu na polityczne losy wspólnoty. Nie wymaga rozległych uzasadnień stwierdzenie o zasadniczej odmienności projektu politycznego zawartego na kartach Nowej Heloizy. Tu bowiem mamy do czynienia z relacją pan - sługa, z jednostronnym aktem stanowienia prawa poprzez decyzje gospodarza, z brakiem współdecydowania o losach wspólnoty przez sługi. Jeśli Prawodawca Umowy... musi być półbogiem - to Wolmar z konieczności jest samym bogiem. Rousseau nie przewiduje bowiem możliwości jego skorumpowania przez „wolę partykularną”, chęć wykorzystania poddanych jako narzędzi zaspakajania własnych pragnień bez oglądania się na ich dobro ${ }^{17}$.

W związku z tym, Umowa społeczna umiejscawia Prawodawcę poniekąd na uboczu życia społeczno-politycznego, Nowa Heloiza czyni zaś z niego punkt centralny wspólnoty, jej duszę, serce i mózg, osobę - niedościgniony wzór cnót, do którego poddani nieustannie próbują równać ${ }^{18}$.

\section{Słudzy - obywatele}

Nie z każdego ludu da się jednak uczynić obywateli w prawdziwym tego słowa znaczeniu. Tak jak Umowa... zawiera szereg warunków, które społeczność musi spełnić, by praca Ustawodawcy nie poszła na marne, podobnie i gospodarze Clarens wiedzą, że niektórzy ludzie są na tyle zepsutymi, że przyjęcie ich na służbę nieuchronnie sprowadzić musi nieszczęście i powolny rozpad całej wspólnoty. Podobnie jak w pozostałych swych dziełach, tak

17 Kwestia zinstytucjonalizowanej nierówności panującej w Clarens stanowi zdaniem Starobinskiego główną różnicę konstruktu politycznego prezentowanego w Nowej Heloizie i Umowie społecznej (J. Starobinski, Jean-Jacques Rousseau. Przejrzystość i przeszkoda oraz siedem esejów o Rousseau, przeł. J. Wojcieszak, Warszawa 2000, s. 120-123). Choć bowiem de facto w obydwu dziełach mamy do czynienia z jawną manipulacją dokonywaną przez Prawodawcę na ludzie, to jednak Umowa... zakłada konieczność ukrycia tego przymusu. Świadomość samodzielności i odpowiedzialności za losy wspólnoty ma tam stanowić środek pedagogiczny. W Clarens jest inaczej - tu obywatele są tego przymusu świadomi. Co więcej, budzi on ich „naturalny” sprzeciw (por. J. J. Rousseau, Nowa..., s. 256-257).

18 Zob. tamże, s. 255. 
i tutaj Rousseau przestrzega najbardziej przed zwyczajami przeniesionymi z miasta, przed zepsuciem „towarzystwa”, przed całym złem reprezentowanym przez moralność Paryża ${ }^{19}$. Dla krnąbrnych, zdegenerowanych, spaczonych partykularyzmem dusz nie ma już ratunku. Dlatego też bacznie sprawdzają państwo Wolmar każdego, kto aspiruje do roli ich sług. Oczekiwania są łatwe do precyzowania: „(P)ierwsze żądanie państwa to uczciwość, drugie miłość do pana, trzecie służenie mu według jego woli; ale wystarczy rozsądnego pana i pojętnego sługi, aby trzecie wypływało zawsze z dwóch poprzednich"20. Warunkiem wszystkich cnót jest jednak posiadanie, choć w pewnym stopniu, pozbawionej cynizmu pierwotnej naiwności i prostoduszności.

Odpowiednie dobranie sług to już połowa sukcesu, bowiem „gdy już są jak najstaranniej dobrani, dokonuje się mimowolne, rzekłbyś, zjednoczenie, niemal wymuszone potrzebą wzajemnych usług, aż każdy pojmie własny interes w zaskarbieniu sympatii wszystkich towarzyszy"21. Mimo że ta symbioza będąca celem zabiegów gospodarzy teoretycznie nie wyklucza takiej możliwości, wszyscy słudzy powinni być równymi co do zakresu obowiązków względem państwa. Nie ma tu miejsca na uprzywilejowanie jednych względem drugich ${ }^{22}$. Tak jak faworyzowanie jednego z dzieci przez rodziców może stanowić zarzewie konfliktu z rodzeństwem, tak i we wspólnocie politycznej wobec wszystkich powinno stawiać się te same wymagania. Wszelkie działania mogące rodzić spory między obywatelami likwidowane są jak najszybciej i jak najdokładniej. Brak tu tolerancji dla donosicielstwa i prób przypodobania się państwu, dla rozwijania niskich pobudek, dla stawiania swego indywidualnego interesu nad „dobro wspólne” - ideałem byłaby wręcz niezdolność rozróżnienia między tymi dwiema kategoriami.

\section{Relacje władza - poddani}

$\mathrm{U}$ żadnego innego z les philosophes dialektyka idei racjonalistycznego indywidualizmu i mistycznego kolektywizmu, podziału na ,ja” i „oni” oraz roztopienia jednostki w nieokreślonym „my”, nie wystąpiła z takim natężeniem, jak miało to miejsce u Rousseau ${ }^{23}$. Z całą siłą obraz prób przezwycięża-

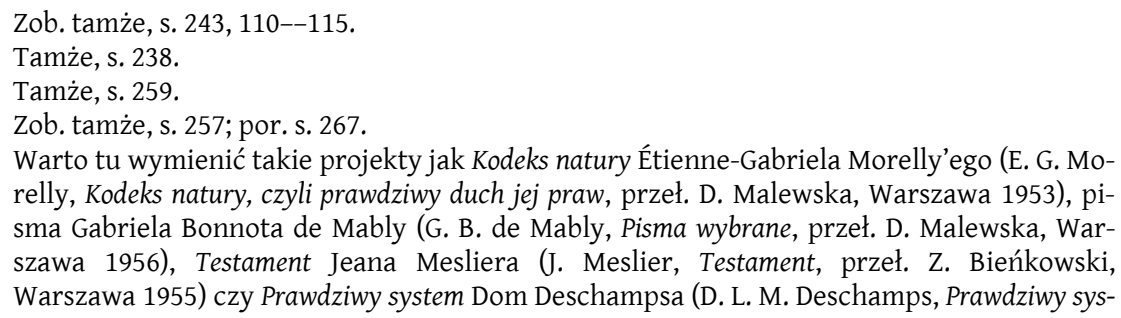
relly, Kodeks natury, czyli prawdziwy duch jej praw, przeł. D. Malewska, Warszawa 1953), pisma Gabriela Bonnota de Mably (G. B. de Mably, Pisma wybrane, przeł. D. Malewska, Warszawa 1956), Testament Jeana Mesliera (J. Meslier, Testament, przeł. Z. Bieńkowski, Warszawa 1955) czy Prawdziwy system Dom Deschampsa (D. L. M. Deschamps, Prawdziwy sys- 
nia tego dualizmu uderza w „Nowej Heloizie”. Tu właśnie literacką formę przybiera nieśmiało kreślona w innych, ściśle filozoficznych dziełach, wizja quasi-antycznej wspólnoty politycznej, w której miejsce każdego obywatela jest ściśle określone, zaś wykonywanie przypisanych mu funkcji stanowi źródło jego spełnienia i szczęścia.

Tym, co uderza od razu jest fakt, że czytelnik tej powieści ma do czynienia z dziwnym melanżem typów charakterologicznych jej bohaterów. W harmonii swoistej symbiozy współegzystują tu bowiem postacie o osobowościach na tyle różnych, że ciężko byłoby przypuszczać, że może między nimi wywiązać się jakakolwiek nić porozumienia. Cóż bowiem może łączyć gospodarza domu - barona de Wolmar - bohaterskiego oficera, człowieka wszechstronnie wykształconego, otwartego, opanowanego, stanowczego i pewnego siebie filantropa $\mathrm{z}$ jego poddanymi, których przed upadkiem w upodlenie właściwe ich stanowi chroni jedynie bezwzględna $\mathrm{w}$ racjonalizmie swej konstrukcji organizacja życia społecznego? Gdzie szukać źródeł więzi łączącej indywidualistę i intelektualistę, bez wątpienia zrodzonego przez edukację choćby tylko zbliżoną do tej, której linię nakreślił Rousseau na kartach Emila..., z poczciwymi, ale, używając dzisiejszej terminologii z zakresu nauk społecznych, całkowicie „zewnątrzsterownymi” sługami, bez opieki swego pana skazanymi na łaskę i niełaskę powszechnych opinii, niezdolnymi do zdystansowanego oglądu swej sytuacji i przeciwstawienia się społecznym wynaturzeniom? Jak możliwe jest ułożenie współżycia tych dwu typów ludzi inaczej niż tylko w oparciu o przymus, pewien system nakazów władcy i bezwzględne podporządkowanie nierozumnych poddanych? Czy możliwa jest taka organizacja życia społecznego, która zapewni szczęście i wolność (lub choćby tylko przekonanie o byciu wolnym) jednostkom tak różnym?

Mimo pozornych sprzeczności dążeń, tego typu symbioza to główny cel autora Nowej Heloizy. Właśnie tutaj, w Clarens, „(S)łudzy wiedzą, że najlepszym dla nich zabezpieczeniem jest złączenie własnego losu z losem pana oraz że tak długo, jak się utrzyma dobrobyt w domu, im również niczego nie zabraknie. Służąc, doglądają własnej ojcowizny; pomnażają ją, oddając usługi z przyjemnością - i w tym leży ich największy interes. (...) Wszystko robi się tutaj przez przywiązanie; rzekłbyś, że te sprzedajne dusze oczyszczają się, wstępując do przybytku mądrości i zgody. Rzekłbyś, że jakaś cząstka mądro-

tem, czyli rozwiązanie zagadki metafizyki i moralności, przeł. B. Baczko, Warszawa 1967). Zob. M. Blaszke, dz. cyt., s. 65-83. 
ści pana i uczuć pani udziela się każdemu z ich ludzi; tak wydają się rozsądni, dobroczynni, uczciwi, wyżsi nad własny stan"24.

„Połączenie losów” - oto cel Rousseau. Środek - to „przywiązanie”, „oczyszczenie dusz". Gwarancję jedności i etyczności wspólnoty stanowić ma duchowe przemienienie obywateli, uczynienie z jednostek podatnych na egoizm i stawianie partykularnych interesów ponad wszystko inne, może nie tyle altruistów, ile osób odczuwających potrzebę dbałości o dobro innych przynajmniej na równi ze swoim. Dobro pewnego „ja" przeciw dobru pewnego „ty” ulega transformacji w, nieznane do tej pory, „dobro wspólne”. Wola mego dobrobytu zmienia się w ,wolę powszechną". Warunkiem budowy wspólnoty idealnej jest przemiana jej członków w idealnych obywateli.

Same instytucjonalne ramy nie wystarczą, by z egoistycznych indywidualistów uczynić patriotów, dobrych sąsiadów i obywateli. Mylili się Bernard Mandeville i Alexander Pope, po Rousseau mylić się będą także - Kant wysuwający koncepcję „państwa diabłów”, Jeremy Bentham i libertariańscy zwolennicy różnorakich teorii „spontanicznego ładu”" ${ }^{25}$, wońcu też, co może niektórych dziwić akurat w takim zestawieniu, John Rawls oraz przedstawiciele tzw. Public Choice School. Ludzkie wady nie odwrócą się same na dobro, egoizmy nie będą się wzajemnie temperować w racjonalnej obawie o przyszłość indywidualnego dobrobytu. Jedynym sposobem na zaprowadzenie rządów „dobra wspólnego” jest sprawienie, by obywatele niczego poza nim nie widzieli, by we współobywatelach odkryli swoich braci, a w swym władcy - ojca ${ }^{26}$. „I czy błądzę, milordzie, porównując tak kochanych państwa do ojców, a ich służbę do dzieci? Widzisz przecie, że sami się za nich uważają"27.

Głównym problemem polityki, najtrudniejszym ze stojących przed nią zadań, jej swoistą „kwadraturą koła”, jak określił to sam Rousseau ${ }^{28}$, jest uczynienie obywateli skłonnymi do postrzegania siebie z perspektywy moralnej całości, jaką stanowi wspólnota. Jak tego dokonać? Należy sprawić, by to, co słuszne, stało się nawykiem, by to, co obowiązkowe, nieodłącznie powiązane zostało z odczuciem wolności wyboru. „Cała sztuka polega na ukryciu owego przymusu pod zasłoną przyjemności czy zysku, tak, że uważają się

\footnotetext{
J. J. Rousseau, Nowa..., s. 268.

M. Qvortrup, The Political Philosophy of Jean-Jacques Rousseau. The Impossibility of Reason, Manchester-New York 2003, s. 27-36.

Zob. J. J. Rousseau, dz. cyt., s. 264-265; por. s. 344-345.

Tamże, s. 241.

28 Tenże, Uwagi o rządzie polskim, przeł. M. Staszewski w: tenże, Umowa społeczna oraz Uwagi o rzadzie polskim, Przedmowa do «Narcyza», List o widowiskach, List o Opatrzności, Listy moralne, List do arcybiskupa de Beaumont, Listy do Malesherbesa, Warszawa 1966, s. 187.
} 
za całkiem wolnych robiąc to, do czego są zobowiązani" ${ }^{29}$. Gdzie bije źródło tego przymusu? Bez wątpienia z nakazów barona de Wolmar i Julii czyniących egzystencję społeczną, najbardziej jak tylko to możliwe, zgodną z tymi skłonnościami „obywateli”, które nie są dla niej destrukcyjnymi. Czy jest to przymus, który poddani nałożyliby na siebie, gdyby tylko byli tak rozsądni jak ich państwo? Zapewne przyjąłby on wówczas zupełnie inną postać - tę obecną u barona de Wolmar i Julii. Zdaje się, że Rousseau daje tu wyraz swemu ostatecznemu zwątpieniu w równość ludzkich predyspozycji. Są bowiem ci, którzy zdolni są do nałożenia na siebie rozumnych obowiązków - stanowią tym samym pewną „oświeconą elitę”. Niestety zawsze w większości będą ci, którzy do podobnego wysiłku są niezdolni, ci, którzy albo widzą, co należy uczynić, lecz brak im sił, by spełnić powinność albo w ogóle nie są w stanie usłyszeć nakazów rozumu. Trudno o lepszy przykład zerwania z tradycją kontynentalnego oświecenia ${ }^{30}$.

Czy przykrywając przymus zasłoną przyjemności lub interesu nakazy te czynią poddanych wolnymi, „prawdziwie wolnymi”? W pewnym sensie tak. Skoro poddanie się społecznej opinii, sławne „porównywanie się"31 jest grzechem prowadzącym do zatracenia swego ja, „(A)lbowiem żeby dojść do uznania siebie w innych [...] trzeba najpierw odrzucić siebie w sobie"32 - to zażegnanie tego niebezpieczeństwa można utożsamiać z wyzwoleniem ${ }^{33}$.

Zadaniem barona de Wolmar, podobnego do Prawodawcy z Umowy społecznej, jest dać umysłom słabszym, niż jego własny, prawa - takie, dzięki którym to, co w innych okolicznościach poczułyby jako ograniczenie swobody, rzeczywistość wobec siebie wyalienowaną, teraz uznają za niezbędny składnik własnego szczęścia. Nie chodzi przy tym o prawa pozytywne ${ }^{34}$, lecz o zwyczaj „silniejszy od samej władzy”35. Podporządkowanie pozytywnemu prawodawstwu wymaga posłuszeństwa jedynie wówczas, gdy czyjaś obec-

29 Tenże, Nowa..., s. 248-249; por. s. 253.

30 Zob. M. Qvortrup, dz. cyt., s. 23-24,

31 P. Mannent, Intelektualna historia liberalizmu, przeł. M. Miszalski, Kraków 1994, s. 101.

32 C. Lévi-Strauss, Jan Jakub Rousseau, twórca nauk humanistycznych, przeł. L. Kolankiewicz, „Twórczość” 1984, nr 6, s. 83.

33 Zob. G. Compayré, J.-J. Rousseau et l'Education de la Nature, Paris 1901, s. 24-29.

34 „[...] aby tworzący się lud polubił zdrowe zasady polityczne i trzymał się podstawowych reguł rozumu państwowego trzeba, żeby skutek mógł się stać przyczyną, żeby duch społeczny, który ma być rezultatem organizacji, przyświecał samemu organizmowi, i żeby ludzie przed wprowadzeniem ustaw byli tym, czym mają stać się przez nie" J. J. Rousseau, Umowa..., s. 39 ; por. tenże, Ekonomia...,. s. 299. Jak trafnie wyraził to Bronisław Baczko, Prawodawca „ma [...] zjednoczyć ludzi na mocy ich dobrowolnego przyzwolenia, ale w myśl zasad, których oni sami nie rozumieją i do których mają dopiero wznieść się moralnie, ma więc ich dźwignąć ponad samych siebie" (B. Baczko, Hegel a Rousseau, w: tenże, Człowiek i światopoglądy, Warszawa 1965, s. 140).

35 J. J. Rousseau, Nowa..., s. 244; por. s. 248, 253. 
ność grozi karą za czyn zabroniony. Używając późniejszego, kantowskiego rozróżnienia, prawo pozytywne wymaga działań „zgodnych z obowiązkiem”, ale nie „z obowiązku”. Nie opiera się na internalizacji zasad, ale na konformizmie wobec nich. Tymczasem Rousseau wyraźnie chodzi o to, by taka różnica nie istniała, aby życie obywatela nie było życiem „rozdwojonym” między sferę publiczną i prywatną, z których każda generuje odmienne, częstokroć sprzeczne, wymagania. W idealnej wspólnocie Rousseau nie ma miejsca na sytuację tragiczną - fatalizm nieuchronnego konfliktu wartości czyniący każdą z możliwych dróg postępowania równie nieszczęsną w konsekwencjach.

Porządek panujący w społeczności odwzorowuje zawsze porządek duszy jej gospodarza. Skoro zaś baron Wolmar to jednostka mądra, niemalże pozbawiona namiętności, wyważona w sądach i trafnie oceniająca ludzkie możliwości ${ }^{36}$, nie dziwi fakt, że „(P)orządek, który ustanowił w swoim domu, jest odbiciem ładu, jaki panuje w głębi jego duszy, i w małym gospodarstwie zdaje się naśladować porządek widoczny w układzie świata. Nie widać tam ani owej nieubłaganej regularności, która bardziej krępuje, niż pomaga, a znośną jest tylko dla człowieka, który ją innym narzuca, ani tego źle rozumianego zamieszania, które, wszystko naraz dając, nie pozwala z niczego korzystać. Tutaj poznaje się wszędzie rękę pana, ale nigdy się jej nie czuje; tak dobrze ułożył pierwsze rozporządzenia, że teraz wszystko idzie samo"37.

Każdy z członków wspólnoty ma być ponad wszystko obywatelem. Swe prywatne życie oglądać ma oczami całej wspólnoty, chcieć ma „wolą powszechną", samego siebie postrzegać poprzez udział we wspólnocie i swój wkład w jej życie. Każdy z nich chcieć ma tego samego. Prawodawca, baron Wolmar, „powinien [...] odebrać człowiekowi jego własne siły, aby mu udzielić sił cudzych, z których nie mógłby korzystać bez pomocy drugiego. Im bardziej jego siły naturalne zamarły i zanikły, tym większe i trwalsze są siły nabyte i tym mocniejsze i doskonalsze jest całe urządzenie. Tak więc, jeżeli każdy obywatel jest niczym i nie może nic zrobić bez pomocy innych, a siła osiągnięta przez całość dorównuje lub przewyższa sumę sił wszystkich jednostek, można powiedzieć, że prawodawstwo osiągnęło najwyższy stopień doskonałości, jaki mogło osiągnąć”38. Jak pisze Jean Starobinski, „(S)prawcie, aby każdy widział siebie i kochał siebie w innych, tak aby w ten sposób wszyscy byli związani silniejszą więzią"39. Doskonale obrazuje to analogia „zgro-

\footnotetext{
Zob. tamże, s. 204.

Tamże, s. 205; por. s. 264

38 Tenże, Umowa..., s. 37-38; por. B. Baczko, Rousseau: samotność $i$ wspólnota, Warszawa 1964, s. 542-543.

39 J. Starobinski, dz. cyt., s. 119.
} 
madzenia pod wierzbą" - tej formy samorządu, gdzie jeden z obywateli, pośród milczenia pozostałych, bezbłędnie wypowiada to, co myślą i czują wszyscy. Brak tu dyskusji, ścierania się argumentacji, walki interesów, brak w końcu i konsensusu - jest bowiem zupełnie zbyteczny ${ }^{40}$.

Nie oznacza to jednak takiego podporządkowania i heteronomii woli, z jaką mamy do czynienia we współczesnych Rousseau, zdegenerowanych społecznościach miejskich. Fakt - w każdej z nich brak autonomii, prawdziwego indywidualizmu w kantowskim znaczeniu. Mimo to różnice są jednak znaczne. Najlepiej przedstawia je obraz Paryża, który kreśli Saint-Preux w jednym z listów do Julii (część II, list XIV). Jest to miasto zakłamania, gdzie słowa nie pociągają za sobą czynów, „(G)dyby to wszystko było szczere i rzetelne, żaden inny naród nie okazałby się równie obojętny wobec własności i doczekalibyśmy się niemal doskonałej wspólnoty dóbr (...) i Paryż przewyższyłby samą Spartę sprawiedliwością podziałów"41. Co szczególnie uderza tu w porównaniu z organizacją Clarens, to „niewielka liczba mężczyzn i kobiet myślących za wszystkich innych, za których inni mówią i działają, ponieważ zaś każdy troszczy się o własny zysk, nikt o wspólne dobro a poszczególne interesy zawsze się sobie sprzeciwiają, wynikają stąd wieczne zderzenia się fakcji i kabał, przypływ i odpływ uprzedzeń, odmiennych zdań, z tym, że najbardziej zacietrzewieni, podżegani przez innych, prawie nigdy nie wiedzą, o co chodzi"42.

Jakże odmienny obraz relacji społecznych przedstawia Nowa Heloiza. Ukształtowana hierarchia społeczna, ściśle przeznaczone każdemu miejsce we wspólnej egzystencji, w końcu też zwyczajowe przywiązanie zarówno do współobywateli, jak i państwa Wolmar powstrzymują przed pragnieniem wyższego prestiżu, ciągłego posiadania więcej. Tu bowiem najwyższą nagrodą jest uznanie ze strony gospodarzy, można zaś na nie zasłużyć jedynie pracą na rzecz „dobra wspólnego”.

Czy oznacza to eksploatację nieświadomych istnienia przymusu obywateli? Determinację ich woli przeciw poruszeniom ich woli „prawdziwej”, pozbawienie ich możliwości szczęścia i spełnienia? Nie, gdyż ostateczny cel wszystkich tych zabiegów państwa to zawsze właśnie uszczęśliwienie obywateli. Nie jest nim osobisty dobrobyt władców, którzy wyposażeni przez naturę i edukację w umiejętności wpływania na poruszenia woli innych, z dziecinną łatwością mogliby realizować wszelkie swe cele. $\mathrm{Na}$ „wolę powszechną”, „dobro wspólne” musi składać się postulat samorealizacji

40 Por. B. Baczko, Demokracja i konserwatyzm w utopii J. J. Rousseau, „Archiwum Historii Filozofii i Myśli Społecznej" 1964, t. 10, s. 7.

${ }^{41}$ J. J. Rousseau, Nowa..., s. 90.

42 Tamże, s. 92-93. 
obywateli. Sam Rousseau zaznacza, że niejednokrotnie oznaczać to będzie brak podobnego szczęścia państwa Wolmar, gdyż „prości ludzie z Clarens, «podwładni», nie przeżywają zwątpień i rozterek duchowych (...). Na tym polega zarazem wyższość i niższość «podwładnych» wobec ich «panów». Wolmar i Julia (...) nie mogą natomiast być tak szczęśliwi jak oni (...), utożsamiać się do końca z warunkami swej egzystencji”" ${ }^{3}$. Jak widać, najlepsza analogia relacji między władcą a poddanym w Nowej Heloizie to ta między rodzicami i dziećmi. Dzieci nie są świadome wszystkich czekających na nie zagrożeń, kiedy zaś staną z nimi twarzą w twarz - nie są w stanie im zapobiec. Mimo to, jak wyłożył Rousseau w Emilu..., dzieciom nie wolno zakazywać i nakazywać, dzieciom trzeba tłumaczyć, wytworzyć w nich przeświadczenie, że są w stanie dokonać samodzielnych wyborów, zmusić je do poznawczego wysiłku. I to właśnie czynią państwo Wolmar.

\section{Ile rozumu w polityce?}

Naturalnie takie ułożenie stosunków społecznych i politycznych budzi wiele wątpliwości. Cały czas powracają pytania: czy bez autonomii można mówić w jakimkolwiek sensie o wolności?, czy w ogóle można zastosować pojęcie 'wolności' do któregokolwiek z bohaterów Nowej Heloizy, jeśli zaś tak, to do którego? Nasuwa się przynajmniej kilka możliwości odpowiedzi na tak formułowane indagacje. Nie mamy tu do czynienia z ideałem wolności „negatywnej”, zgodnie z terminologią późniejszej literatury filozoficznopolitycznej, to jest oczywiste. Bez wątpienia wolność nie polega według Rousseau na samowoli - o tę przecież najłatwiej w wielkim mieście, gdzie każdy jest, po pierwsze - w pewnym sensie, anonimowy, po drugie zaś - ma ograniczone tylko własną wyobraźnią możliwości pozyskiwania środków materialnych i zaspakajania swych pragnień. Nie o taką wolność chodzi Rousseau, według którego, obok fizycznej niewoli najgorsza jest ta wobec własnych namiętności. Kiedy autor Umowy... pisze o wolności, ma z pewnością na myśli berlinowską wolność „do” - wolność samorealizacji poprzez życie „zgodne z naturą"4.

Można jednak, za Johnem Grayem ${ }^{45}$, wyróżnić dwa rodzaje wolności pozytywnej. Jedna to ta indywidualistyczna - upatrująca postulowanego ideału w działaniach jednostek ,autonomicznych”, tzn. zdolnych do zdystansowania się w stosunku zarówno do wspólnoty, w której żyją, jak i do swych, przynajmniej niektórych, pragnień. Taki typ wolności znajduje swe najdo-

\footnotetext{
43 B. Baczko, dz. cyt., s. 19

44 T. Davidson, Rousseau and Education According to Nature, New York 1900, s. 77-82.

45 Zob. J. Gray, Liberalizm, przeł. R. Dziubecka, Kraków 1994, s. 75-76.
} 
skonalsze egzemplifikacje w pismach Kanta i niektórych późniejszych liberałów „reformowanych” - Johna Stuarta Milla i, choć na nieco inny sposób, Thomasa Hilla Greena. Filozofowie ci zakładają, że jednostki są racjonalne, wolne oraz że, w sprzyjających okolicznościach, ich wola zdolna jest „nadążyć” za nakazami rozumu.

Drugi typ wolności pozytywnej znacznie różni się od wcześniejszego. Jest on tożsamy z koncepcją "kolektywnego samostanowienia”" jako urzeczywistnienia wolności, w której najwyższej cnoty nie upatruje się już w indywidualnej presji doskonalenia moralnego czy podporządkowania dyktowanym przez rozum imperatywom, ale w konformizmie wobec odpowiednio ułożonych instytucji wspólnoty politycznej. Ten ideał Gray przypisuje jednoznacznie tradycji heglowskiej.

Który z tych sposobów rozumienia wolności jest bardziej właściwy pismom Rousseau? Ci, którzy upatrują w nim protoplastę kantyzmu skłonni są odpowiadać - ten pierwszy, „indywidualistyczny”. Na poparcie swej tezy wymieniają cytaty z Emila..., którego główne przesłanie sprowadza się do postulatu rozumnej korekty namiętności, do racjonalnego skanalizowania ich i odpowiedniego ukierunkowania. Drugie dzieło, w którym szukają oparcia, to Umowa społeczna. Nieprecyzyjna konstrukcja „woli powszechnej” pozwala różnorako ją odczytywać. Jedna z interpretacji - ta sugerująca "totalitarny” charakter volonté générale - stanowi bezpośrednią konsekwencję przynajmniej trzech czynników. Pierwszy to fakt niezrozumiałego sposobu odczytywania nakazów woli powszechnej (tzw. „zasada plus-minus”), drugi - konieczność istnienia Prawodawcy, który miałby dzięki najróżniejszym zabiegom, m.in. religii obywatelskiej, kształtować przekonania obywateli i prowadzić do jej wyłonienia, trzeci to fakt uznania wszechmocy volonté générale nieograniczonej nakazami prawa natury. Nie jest to jednak jedyna wykładnia filozofii politycznej Rousseau. Inne odczytanie jego pism pozwala upatrywać w nich zapowiedzi nie tyle terroru rewolucji francuskiej czy politycznej gnozy dwudziestowiecznych totalitaryzmów, ile raczej Rawlsowskiej Teorii sprawiedliwości. Na korzyść tej interpretacji „woli powszechnej” przemawia m.in. rousseau'owski nakaz upatrywania w niej źródła samoograniczenia jednostek w imię realizacji własnego interesu.

Tok rozumowania zwolenników „demokratycznej” interpretacji volonté générale jest prosty. Wszystko zależy od odpowiedniego ułożenia instytucji politycznych. Nie trzeba bowiem zmieniać natury jednostek, aby ich koegzystencja nie kończyła się zawsze hobbesowskim bellum omnium contra omnes. Wystarczy, aby przed głosowaniem nad daną ustawą nie mogły się

46 Tamże, s. 76. 
one porozumieć. Nie będąc wówczas wyrazicielami potrzeb jakiejś grupy, będą starały się zabiegać o realizację swego własnego interesu. Każda racjonalna jednostka zagłosuje wówczas tak samo - w trosce o własny interes, mimowolnie chroniła też będzie interesy wszystkich pozostałych obywateli. Tak właśnie, zdaniem niektórych, należy rozumieć zdania otwierające Umowę...: „(P)ragnę zbadać, czy może istnieć w ustroju społecznym jakaś reguła rządzenia prawowita i pewna, biorąc ludzi takimi, jakimi są, a prawa takimi, jak być mogą. Będę się zawsze starał przy tym badaniu łączyć to, na co prawo pozwala, z tym, co nakazuje interes, aby sprawiedliwość i użyteczność nie zostały rozdzielone" ${ }^{47}$. A zatem „wola partykularna" nie stanowi zła bezwzględnego. Przy odpowiednim ułożeniu procedur ustawodawczych można $\mathrm{z}$ niej wywnioskować nakazy volonté générale. Badacze opowiadający się za taką interpretacją mówią więc: Rousseau nie chce zmieniać człowieka, bierze go takim, jakim jest, a nie takim, jakim mógłby być lub jakim był w domniemanym „złotym wieku” ludzkości. Autor Umowy... łączy też sprawiedliwość i użyteczność - użyteczność, polegająca na ważeniu konsekwencji możliwych sposobów działania i wyborze tej najbardziej korzystnej, to zasada, którą kierują się jednostki poddane nakazom „woli partykularnej”, sprawiedliwość zaś wyraża „wola powszechna”. Pierwsza stanowi warunek konieczny wyłonienia drugiej.

Można więc tak ułożyć stosunki społeczno-polityczne, by „wole partykularne” z konieczności prowadziły do wyłonienia „woli powszechnej”. Co więcej, zasada dochodzenia tego, jaki jest naprawdę nakaz volonté générale tzw. „zasada plus-minus”48 bezpośrednio wskazuje możliwość „wyliczenia”, która z ustaw jest tą realizującą „dobro wspólne”. Wystarczy więc odpowiednio skonstruować proces ustawodawczy, a "wola powszechna" ujawni się sama poprzez racjonalne decyzje dążących do samoograniczenia obywateli. W sytuacji idealnej, która niestety nigdy nie będzie miała miejsca, jednomyślność wyniku głosowania byłaby najwyższym dowodem na to, że dana uchwała zgodna jest z volonté générale. Analogia z rawlsowską „zasłoną niewiedzy” i „zasadą maximinu” jest tu oczywista i chyba nie wymaga dalszego rozwinięcia.

Zwolennicy interpretacji odmiennej - ci upatrujący w pismach Rousseau realizacji ideału wolności pozytywnej „skolektywizowanej”, nawołują-

\footnotetext{
J. J. Rousseau, Umowa..., s. 11.

"Często zdarza się znaczna różnica między wolą wszystkich a wolą powszechną; ta ostatnia uwzględnia interes wspólny, tamta interes prywatny i jest tylko sumą woli prywatnych; ale odejmijmy od tych samych woli plusy i minusy, które się nawzajem znoszą, a pozostanie jako wynik tych różnic - wola powszechna" (tamże, s. 29; por. A. Peretiatkowicz, Jan Jakub Rousseau - filozof demokracji społecznej, Poznań 1949, s. 202).
} 
cej do rewitalizacji antycznej polis, konkretnie zaś, tak gloryfikowanej przez autora Wyznań, Sparty - odmiennie odczytują Umowę.... Zwracają oni uwagę na te jej fragmenty, które jednoznacznie wskazują zmianę świadomości i charakteru obywateli jako warunek sine qua non jakiejkolwiek politycznej reformy. Same instytucje nie uczynią ludzi lepszymi, niż są aktualnie. Owszem, być może da się odpowiednio pokierować ludzkimi egoizmami, może dałoby się nawet ułożyć stosunki polityczne tak, by ograniczyć „wojnę wszystkich ze wszystkimi”. Pytanie tylko, czy jest to zmiana, którą Rousseau rzeczywiście postuluje. Zgodnie z tą interpretacją dorobku Rousseau - nie. Szczęście obywateli wspólnoty idealnej leży w wyzwoleniu spod rządów „woli partykularnych”, czyli od ciągłej pogoni za maksymalizacją indywidualnych korzyści kosztem pozostałych obywateli ${ }^{49}$. Postulowana „wola powszechna” stanowi źródłowe i egzystencjalne przeciwieństwo „woli partykularnej" i, jako taka, musi kierować osobami zupełnie odmiennymi niż utylitarnie postrzegający rzeczywistość społeczną „indywidualiści”. Rządy „woli powszechnej” możliwe są jedynie we wspólnocie, w której obywatele przedkładają jej interes nad własny lub nawet oba utożsamiają ${ }^{50}$ - to zaś możliwe jest tylko dzięki ich moralnej reformie. Potrzeba takiej transformacji to w końcu główne uzasadnienie dla istnienia Prawodawcy, który jest wychowawcą narodu budzącym w nim obywatelskiego ducha.

Z łatwością można dostrzec, że oba te ideały znajdują swe zastosowanie na kartach Nowej Heloizy ${ }^{51}$. Pierwszy, ten oświeceniowego racjonalizmu i autonomii, personifikują gospodarze Clarens. Są zbyt świadomi ludzkiej natury, własnych możliwości i ograniczeń, by móc bezrefleksyjnie stopić się ze wspólnotą. Nie jest to także ich przeznaczeniem choćby z jeszcze jednego

49 Taka interpretacja pozwala uznać ostateczną spójność wszystkich dzieł Rousseau, z których pierwsze Rozprawy stanowią jedynie krytyczną propedeutykę późniejszych projektów pozytywnych - tych zawartych w Emilu... i Umowie.... „Polityczne” fragmenty Nowej Heloizy, Projekt konstytucji dla Korsyki oraz Uwagi nad rządem polskim miałyby stanowić zróżnicowane próby aplikacji wcześniejszych rozstrzygnięć teoretycznych.

50 Zob. J. J. Rousseau, Nowa..., s. 268.

51 Podobnie elitarystyczne projekty niedługo po Rousseau wysuwali także Adam Heinrich Müller i Friedrich Wilhelm Joseph Schelling. Szczególnie uwidacznia się to przy zagadnieniu odpowiedzialności moralnej. W przypadku pierwszego z tych filozofów, odpowiedzialność jednostkowa opiera się na możliwości „pełnego zharmonizowania jednostki z zasadą określającą życie społeczne, z ideą swoistości narodowej” (Z. Kuderowicz, Doktryna moralna młodego Hegla, Warszawa 1962, s. 279), zaś do takiego zharmonizowania zdolne są jedynie wyjątkowe jednostki. Przypadają im we wspólnocie role sędziego, męża stanu, monarchy. W przypadku Schellinga odpowiedzialność moralna przypisana zostaje artyście - jedynej jednostce zdolnej w pełni realizować swe zamierzenia. Tym, co od razu zwraca uwagę, jest irracjonalistyczny charakter tych koncepcji. To umiejscawia je w opozycji do projektu Rousseau, w którym odpowiedzialność moralna spada na jednostki racjonalne, zdolne zapanować nad swymi namiętnościami. 
powodu. Dzięki takim osobom wspólnoty „doskonałe”, które poprzez spojenie poszczególnych jednostek w jedno „ciało moralne i zbiorowe” (corps moral et collectif), pozwalają uniknąć negatywnych skutków społecznej egzystencji jednostek, obronić prowincjonalny modus vivendi przed przekleństwem „porównywania się” właściwym na przykład Paryżowi, są w ogóle możliwe. Żeby zaplanować porządek społeczny i polityczny, „potrzeba umysłu wyższego, który znałby wszystkie namiętności ludzkie, a sam nie doznawał żadnej; który byłby pozbawiony wszelkiego związku z naturą, a znał ją gruntownie; którego szczęście byłoby od nas niezależne, a który jednak chciałby się naszym szczęściem zająć; który wreszcie, zachowując sobie w procesie dziejowym odległą sławę, mógłby pracować w jednym wieku, a zbierać plony w drugim"52.

I tacy są właśnie państwo Wolmar. Ich cnota nie opiera się dobrotliwej naiwności chłopa, ale na świadomości ludzkich ograniczeń i zgubności ludzkich namiętności. Niewielu może poznać smak ulegania ludzkim przywarom i wydostać się spod ich wpływu. Ta dojrzałość, wyrwanie ze stanu intelektualnego i emocjonalnego dzieciństwa, zerwanie zakazanego owocu z drzewa poznania dobra i zła, pokutuje jednak w bardzo dotkliwy sposób. Zarówno baron, jak i jego małżonka tracą możliwość bycia prawdziwie szczęśliwymi. Są skazani na samotność, autonomię, na zawsze zostali wyrwani z duchowej więzi łączącej ich podwładnych.

Inaczej rzecz się ma ze sługami i chłopami zamieszkującymi Clarens. Reprezentują oni drugi typ wolności pozytywnej. To ludzie prawdziwie szczęśliwi. Rządzeni uczuciami, spojeni w jedną całość, w ramach której każdy ma wyznaczone miejsce oraz związane $z$ nim obowiązki i prawa. Żaden nie „porównuje się" z drugim, gdyż doskonale wie, że 1) nie może być nikim innym, zna wyjątkowość swej pozycji we wspólnocie oraz 2) czuje, że najwyższą wartością jest dobro wspólne wszystkich obywateli - „instynktownie" ${ }^{53}$ postrzega samego siebie w symbiozie z pozostałymi i utożsamia swój interes $\mathrm{z}$ interesem wspólnoty. Bezpośredniość i przejrzystość stosunków ${ }^{54}$ tu panujących stanowi tego gwarancję.

\section{J. J. Rousseau, Umowa..., s. 37.}

53 Instynktownie, a nie racjonalnie. Gdyby bowiem wspólnota opierała się na utylitarnym rachunku korzyści płynących z egzystencji wspólnotowej, nieuniknionym byłoby jej zepsucie poprzez partykularyzmy i rychły rozpad.

54 Starobinski dopatruje się zbieżności między elementami teorii prawa wyłożonej na kartach Umowy... i emocjonalnością członków wspólnoty z Nowej Heloizy. Szczególnie widoczna jest, jego zdaniem, w sposobie przeżywania przez nich wspólnych świąt: „(P)odniosłość wspólnego święta ma taką samą strukturę jak wola powszechna w Umowie społecznej. Opis powszechnej radości oddaje liryczny aspekt woli powszechnej [...]. W upojeniu powszechnej radości każdy jest jednocześnie aktorem i widzem; z łatwością odkrywamy tu podwójną 


\section{Podsumowanie}

Czy zasadne jest zatem twierdzenie, że Nowa Heloiza daje możliwość rozstrzygnięcia przynależności Rousseau do jednej z dwu tradycji - oświeceniowego politycznego racjonalizmu bądź romantycznego irracjonalizmu? Zdaje się, że nie. Obydwa paradygmaty myślenia o człowieku i obywatelu, politycznych instytucjach i pełnionej przez nie roli, związane są na tyle mocno, że nie można wyobrazić sobie eliminacji któregokolwiek z nich bez dekonstrukcji wspólnoty Clarens. Jak na osobę miotaną wieloma namiętnościami, Rousseau okazuje się być w pełni świadom złożoności ludzkiej „natury”. Wie, że beztroskie szczęście, umiejscawiane przez filozofów w „złotym wieku" ludzkości, nigdy już nie wróci. Współczesne mu jednostki stoją przed możliwością trojakiego „wyboru” drogi życiowej. Pierwszym z nich jest ten rzucenia się w wir egzystencji typowej dla wielkich miast, ciągłej aspiracji do społecznego awansu, zabiegania o uznanie dla swej powierzchowności. Jest to bez wątpienia najgorsza $\mathrm{z}$ dróg - jednostka zostaje pozbawiona nadziei na osiągnięcie szczęśliwości, jej pycha bowiem nigdy nie znajdzie zaspokojenia.

Drogę drugą mają szansę obrać jedynie nieliczni. Prowadzi ona w kierunku realizacji oświeceniowego ideału osobowości rozumnej, świadomej swego miejsca w świecie i zagrożeń, jakie na nią czekają, ale jednocześnie też „zgodnej z naturą", rozwiniętej harmonijnie, szczerej i bezinteresownej, choć nie naiwnej. To droga, którą kroczą baron Wolmar i Julia. Nie uzyskają na niej bezwzględnej szczęśliwości, tę bowiem, zdaniem Rousseau, daje dopiero kolejna ścieżka.

Tą ostatnią i, jak twierdzą niektórzy - także najbardziej wartościową jest egzystencja wspólnotowa poddanych gospodarzy Clarens. Tylko „zapomnienie się” w egzystencji „moralnego ciała”, które stanowi cała społeczność oparta na przejrzystości kontaktów między współobywatelami, daje możliwość praktykowania „prawdziwej cnoty” i „prawdziwego szczęścia”.

Rousseau zdaje się jednocześnie mówić, że to nie my dokonujemy tego, niewątpliwie jednego z najważniejszych w życiu, wyboru. W pewnym momencie zostaje on podjęty za nas. Nikt $\mathrm{z}$ własnej woli nie może chcieć obrać drogi pierwszej - samozatracenia życia „miejskiego” - gdyż niemożliwym jest osiągnięcie na niej spełnienia. By być zdolnym do obrania drogi drugiej, najczęściej trzeba być poddanym wcześniej edukacji zbliżonej do tej z Emila.... W końcu, by szczęśliwie „roztopić” się we wspólnocie podobnej do tej z Nowej Heloizy, potrzeba Prawodawcy, który podjąłby się próby wyręczenia jednostek w walce $\mathrm{z}$ ich partykularyzmem, z ich miłością własną, amour

kondycję obywatela po zawarciu umowy: jest on jednocześnie «częścią suwerena» i «częścią Państwa»" (J. Starobinski, dz. cyt., s. 119). 
de soi. W końcu ostateczną podstawą każdej cnoty jest mądrośćs5. Nieważne zatem czy przyjmiemy, że najbardziej pożądanym przez Rousseau ideałem jest ten autonomicznego poddania nakazom rozumu lub zupełnie bezrefleksyjnego, na wpół mistycznego pochłonięcia przez życie wspólnoty. Ostatecznie nasze życie i szczęście zawsze zależy od innych.

J A N U S Z G R Y G I E Ń Ć 


\section{Abstract}

It is usually accepted attitude towards La Nouvelle Heloise to treat it as a composition of only literary value. Thus scholars often passed its political content comprised in the construction of ideal community of Clarens (managed by baron de Wolmar and his wife - Julia) over. Author of the essay aims at showing the significance of this project and its compatibility with those outlined in Du Contrat Social - Rousseau's main political work. It turns out that apart from many similarities, as e.g. utilization of the institution of Lawgiver and appropriate organisation of social existance, La Nouvelle Heloise introduces many novelties. One of them is the peculiar arrangement of relations between the host and his servants - arrangement based on serfdom.

Another important issue is the settlement of theoretical dilema present in $\mathrm{Du}$ Contrat Social - that between many possibilities of interpreting cathegory of "general will". In La Nouvelle Heloise it takes the form of strictly ethical nature. Here the term "general will" denotes perfect blending of all individuals into one, social whole, the disposing of personal self. What is really important here, is that bases of such symbiosis are purely irrational, emotional.

But this kind of community wouldn't be able to function properly, if it wasn't for its rational component represented by baron Wolmar anf Julia. They are responsible for ruthlessly consequent supervision of all their servants' activities. Without them, community in Clarens would fall apart. Rationalism, autonomy, irrationalizm and collectivism interpenetrate here - each of them constitute necessary condition of restoring the existence "in accordance with nature". 